\title{
The Candle Scheme for Creating an on-line Computer Science Program - Experiences and Vision
}

\author{
Erkki SUTINEN, Sirpa TORVINEN \\ Department of Computer Science, University of Joensuu \\ P.O. Box 111, FIN-80101 Joensuu, Finland \\ e-mail: \{sutinen,sirpa.torvinen\}@cs.joensuu.fi
}

Received: April 2003

\begin{abstract}
Distance learning programs have rapidly increased during the past few decades. In fall 2000 the University of Joensuu started to offer distance Computer Science (CS) studies to the high school students in surrounding rural areas of Joensuu. In this program high school students study the first year's university level CS studies over the web simultaneously with their regular high school studies. We describe the creation process of our virtual curriculum which is based the so-called Candle scheme. The Candle scheme search the most essential principles needed in online course design, supporting a student locally in her authentic learning needs via electronic tools in a light way. With the Candle scheme we have successfully focused in our design process on the most essential parts of the virtual study process. Our experiences of the Candle scheme in the creation process of the on-line CS program during years 2000-2002 indicate that the scheme is the functional one and expandable to other contexts as well.
\end{abstract}

Key words: Computer Science education, distance learning, on-line learning, virtual learning.

\section{Introduction}

In the past two decades all kinds of distance learning programs have rapidly increased. In the beginning teachers simply turned their learning material to the form of hypertext bringing plenty of web-based materials available all the way from the elementary schools up to the university-level. Farrell et al. (1999) made in year 1999 an extensive snapshot of the state of virtual education development in the major regions of the world. They defined virtual education as something that is heard with an increasing frequency, as the use of information and communication technologies becomes ever more present in conducting open and distance education. They considered that the label virtual is frequently used mutually with other labels like open and distance learning, distributed learning, networked learning, web-based learning, and computer learning. Current strategies typically involve the use of either synchronous or asynchronous digital networks for the delivery of courses, management of services like registration and records, and the provision of learner support services (Farrell et al., 2001). 
In a virtual learning environment, the roles of students and teachers are changing. Students have to be much more active, they are assumed to be motivated to find out information and search optional materials via Internet. Hope (2001) noticed that teachers and instructors are facilitators who support active technology-mediated student learning rather than sole sources of knowledge. When we change our paper-based teaching model to an interactive one we have to rethink the design and production of our learning resources (Sumner and Taylor, 1998). New media demand new practices; some of the traditional teaching methods are useful even in the web-based teaching, but distance learning has plenty of characteristic methods itself - like communication over the web, shared delivery of materials, interactive working over the web, or virtual team working. Dhanarajan (2001) has developed ten key issues that need to be addressed when designing virtual courses. The most essential demands are the pedagogical skills of teachers and educational administrators, access and equity, standards and assessments, staff training and development, and research. Several distance learning programs have been developed due to the pressure of fashion and trend rather than real need.

The creation process of our distance learning Computer Science (CS) program arose out of two factors; the expectations of the Finnish Ministry of Education funded the Finnish Virtual University project, and the need for higher quality CS teaching in high schools. We made plans for implementation in close co-operation with high school teachers, and created the Candle Scheme to guide us in the process. Thus the Candle scheme has some context dependent elements, like the Finnish educational system or the target group of the students. However, we believe that it can be expanded to other environments, like different kinds of student groups or other cultural contexts, by minor modifications.

\section{First Year University Level Studies in CS over the Web}

Our distance learning program has been developed as a part of the three-year project (2001-2003) to establish the Finnish Virtual University. One of the particular goals of our project is to develop new Computer Science education methods (Haataja et al., 2001). In fall 2000, the Department of Computer Science at the University of Joensuu began offering, within the framework of that project, a university level Introductory Computer Science Curriculum (22.5 European Credit Transfer System credits, cps) to high school students in the surrounding rural region of Joensuu, extending this teaching experiment in the following fall to the rural region of the neighboring province as well. We have now students from a total of 20 rural high schools.

Table 1 gives the contents and schedule of courses during the 1.5 years period. The Curriculum provides basic knowledge of Computer Science to the students.

Students study independently over the Internet using the WebCT learning environment. Almost $98 \%$ of our studies are arranged over the web. During the 1.5 years study process students visit the campus area four times: in the beginning of the study process at the info meeting, two exams and, for the graduation. In addition, we have one week's summer school period where students have some lectures and plenty of teamwork and presentations. 
Table 1

The contents and outline of courses in our on-line CS program

\begin{tabular}{|c|c|c|c|}
\hline Title of the course & ECTS & Contents & Scheduled \\
\hline $\begin{array}{l}\text { Introduction to Computer } \\
\text { Science }\end{array}$ & $3 \mathrm{cps}$ & $\begin{array}{l}\text { General knowledge about IT and } \\
\text { computing. Practical skills of us- } \\
\text { ing word processing and spread- } \\
\text { sheet programs, basics of Unix. }\end{array}$ & First fall semester \\
\hline Programming I & $3 \mathrm{cps}$ & $\begin{array}{l}\text { The idea of algorithms, basic struc- } \\
\text { tures of programming in Java. }\end{array}$ & First fall semester \\
\hline Programming II & $3 \mathrm{cps}$ & $\begin{array}{l}\text { The basics of object-oriented pro- } \\
\text { gramming (classes, objects, graph- } \\
\text { ical programming and event han- } \\
\text { dling). }\end{array}$ & First spring semester \\
\hline $\begin{array}{l}\text { Research fields of Com- } \\
\text { puter Science }\end{array}$ & $3 \mathrm{cps}$ & $\begin{array}{l}\text { Introduction to a selecting of re- } \\
\text { search fields in Computer Science. }\end{array}$ & First spring semester \\
\hline Programming project & $3 \mathrm{cps}$ & $\begin{array}{l}\text { Independent work containing soft- } \\
\text { ware design and programming. }\end{array}$ & $\begin{array}{l}\text { First spring semester } \\
\text { and summer }\end{array}$ \\
\hline Design of algorithms & $3 \mathrm{cps}$ & $\begin{array}{l}\text { An overview of the central issues } \\
\text { of Computer Science, such as algo- } \\
\text { rithms, computation and data struc- } \\
\text { tures. }\end{array}$ & Second fall semester \\
\hline $\begin{array}{l}\text { Hardware, computer ar- } \\
\text { chitecture and operating } \\
\text { system }\end{array}$ & $3 \mathrm{cps}$ & $\begin{array}{l}\text { An overview of issues such as; } \\
\text { architecture of computers, parsers, } \\
\text { system software, databases, and in- } \\
\text { formation systems. }\end{array}$ & Second fall semester \\
\hline $\begin{array}{l}\text { Introduction to the ethics } \\
\text { of computing }\end{array}$ & $1.5 \mathrm{cps}$ & $\begin{array}{l}\text { General knowledge and practice in } \\
\text { the ethics of computing. }\end{array}$ & Second fall semester \\
\hline
\end{tabular}

\section{The Candle Scheme}

The implementation was based on the request of high school teachers who wanted to improve the level of CS teaching in their schools. At the same time the Finnish Ministry of Education started the Finnish Virtual University program. We decided to combine these two interests and created the virtual introductory CS studies for high school students over the web.

\subsection{Structure of the Candle Scheme}

The instructional design of our program was constructed in close collaboration between high school and university teachers. We found that the contribution from the high school teachers was crucial for the development of the Candle scheme, a selecting of principles to guide the design process. Teachers helped us to coordinate the courses with the schedules of the high schools - these differ quite a lot from school to school. A group of high school teachers monitored the course during the whole period of 1.5 years (Haataja et al., 2001).

Fig. 1 illustrates the main elements of the Candle scheme. 


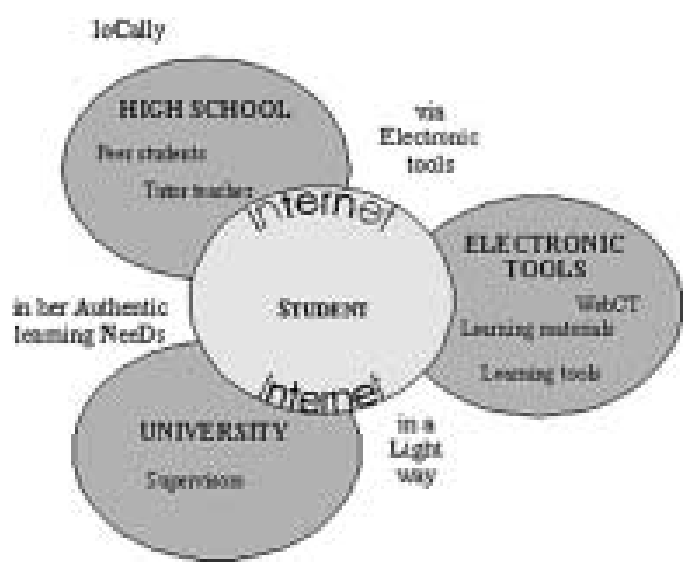

Fig. 1. The main elements in the Candle scheme.

The basis of our creation process was the needs of the students, so the student is the well-justified center point in Fig. 1. Three main elements, university, high school and the Internet, enclose the student. All learning materials and tools are offered to the students by university. Students can get support from tutor teachers and peer students both face-to-face in their own high school and over the web from other high schools as well. Supervisors are staff members of university and co-operate with high schools and with students over the web.

The Candle scheme is designed to support a student (Haataja et al., 2001):

$\square$ loCally,

$\square$ in her Authentic learning NeeDs,

$\square$ in a Light way,

$\square$ via Electronic tools.

In Candle, almost all teaching is carried out via the Internet (Fig. 1) while the students come from all around the surrounding rural region of the university. Students can study locally, at home or at their own high school, instead of spending their time and money for traveling between home and university. One of the major principles has been the equality between high schools; no matter where the high school is situated, students can take part in our program.

The cANDle scheme provides supports in students in their Authentic learning NeeDs by offering real human contacts for the learners. The web site helps the students to communicate with the supervisors and peer students in multiple ways. Supervisors work from the university and hold a at least BSc or MSc degree in CS. In each high school we have one tutor teacher, who usually is either an IT or Mathematics teacher, who helps students especially in the beginning of distance studies. The main purpose of a tutor teacher is to ensure that everybody can use the learning environment and find the courses and assignments. Tutor teachers advice students with the practical problems like submitting exercises or installing Java compiler. In addition they act as contact persons between the 
university and high schools. The main responsibility of teaching lies on the supervisors. The students get valuable help via peer students, both locally and over the web. Real human contacts are also illustrated in Fig. 1.

While sophisticated user interfaces in many web-based educational settings might be confusing for novices we decided to construct our scheme in a Light way. Therefore, candLe keeps the user interface as simple as possible. To make the interface of the learning environment more student-friendly, we hired a fresh high school graduate to design the pages, and give us youthful ideas for assignments. We wanted also keep our webbased learning materials as light as possible, so even over the slow modem connections it is available to use or download our materials.

Another major design principle in candlE is to link the printed learning material with an activating learning environment on the web. The printed material gives students an overall structure and knowledge of the topic while the web materials guide the learners step by step in minor weekly pieces. Additionally we used Electronic learning tools (Fig. 1) like activating visualizing tools, e.g., Jeliot, as students' virtual laboratory. Exercises play an important role in the learning process - especially in programming, learningby-doing is the most effective way to learn. Students have to complete at least one third of all the course assignments; those who exceed the minimum requirement get bonus points for the grade. The bonus point system has been a motivating factor for increasing the response rate.

\subsection{Learning Methods: Candle in Action}

Designing appropriate learning methods and tools for distance learning context is a challenging task. Earlier, e.g., Ellis et al. (1999), Cordani and Tucker (1998) and Watanabe et al. (1999) have discussed the difficulties to select tools appropriate for use distance learning in higher education. Anyway, the common opinion is that a web-based learning environment should provide a rich assortment of learning methods and learning tools in order to provide for each student suitable methods which help him/her in the most efficient way.

Four courses out of eight in our program have the following structure: students study both printed and web-based material; submit weekly assignments and their learning incomes evaluated by exam. Students submit weekly from four to five exercises. Supervisors check all of them, give comments and more detailed advice when needed. Our webmaterials include multiple kinds of visualizations: both interactive and non-interactive applets, and Flash animations. We have also successfully used a program animation program, Jeliot 2000 (Ben-Bassat Levy et al., 2003), in order to deepen the study process in the Programming I-course. Table 2 presents the learning methods and tools used in our program.

In the programming project students develop either individually or in pairs a small piece of software and document it. In spring 2003 we start to use the Problem Processing Assistant (PPA) (Suhonen and Sutinen, 2003) which is developed to support students all the way through their programming process, from conceptual and technical design through implementation up to testing. 
Table 2

Learning methods used

\begin{tabular}{|c|c|c|c|c|}
\hline Method & $\mathbf{C}$ & AND & $\mathbf{L}$ & $\mathbf{E}$ \\
\hline Printed material + web-based material, assignments and exam & $\mathrm{x}$ & $\mathrm{x}$ & $\mathrm{x}$ & $\mathrm{x}$ \\
\hline Animations (Jeliot 2000, Flash, applets) & $\mathrm{x}$ & $\mathrm{x}$ & $\mathrm{x}$ & $\mathrm{x}$ \\
\hline Programming project + PPA & $\mathrm{x}$ & $\mathrm{x}$ & & $\mathrm{x}$ \\
\hline Virtual team work & $\mathrm{x}$ & $\mathrm{x}$ & & $\mathrm{x}$ \\
\hline Essays & $\mathrm{x}$ & & & \\
\hline Portfolios & & $\mathrm{x}$ & & $\mathrm{x}$ \\
\hline Lectures & & $\mathrm{x}$ & & \\
\hline Face-to-face team work & & $\mathrm{x}$ & & \\
\hline Self-tests & $\mathrm{x}$ & $\mathrm{x}$ & & $\mathrm{x}$ \\
\hline Optional virtual team work (discussion forum, IRC, chat, e-mail) & $\mathrm{x}$ & $\mathrm{x}$ & & $\mathrm{x}$ \\
\hline Internet (search for information, contacts etc.) & $\mathrm{x}$ & & $\mathrm{x}$ & $\mathrm{x}$ \\
\hline
\end{tabular}

During one of our courses we have used team work over the web. The members of the group are from different high schools, they work together using the WebCT learning environment and its group work area, producing a common thesis. In additional each student writes his/her personal portfolio where he/she reflects the impacts of virtual teamwork. In "Introduction to the ethics of CS" students write individual essays where they have to consider the ethical point of view in a given case, like illegal copies or using the Internet for terrorism. In this course students have to write a portfolio as well. Students reflect on the development of their attitudes or opinions towards given topic.

During the 1.5 years' period we have a one-week long contact learning period. During this week we have lectures in "Introduction to the Algorithms" course, group work related to both the Algorithm and Ethic courses and feedback session on the programming project.

Based on our experiences we have noticed that a significant part of successful learning process lies in students' own activities like using self-tests, activity in optional virtual team working and use of the Internet (Table 2). The activity of using the discussion forum in the WebCT varied course-wise; the activity is highest in programming courses but not so lower for easier courses. An indication of high motivation is that our students have created discussion groups in IRC where they discuss freely our courses, assignments and problems in the study process.

\section{Experiences}

The on-line CS program was arranged for the first time in fall 2000. For the time being the third group of high school students study in our on-line program. The study process simultaneously with regular high school studies has proved to be a hard one and resulted in several dropouts during the hardest programming courses. Our dropout rates have varied from zero to $42.9 \%$, i.e., depending on the course. Earlier findings show that dropout 
rates in university-level distance learning are, in general, definitely higher than those in conventional university studies. They vary depending on the adopted distance education system and the subject being studied; in Europe between 20\% and 30\% while in Asian countries they around 50\% (Xenos et al., 2002).

After the first year's experiences we evaluated our courses and arrangements by a formative evaluation scheme (Meisalo et al., 2002a) which led to improving especially the difficult parts of the programming courses. In our program the main reason to drop out have been both in year 2000 and 2001 the lack of time. Students have obviously had difficulties to estimate and prioritize the time required for the distance study process along with their high school studies.

In Table 3 we present the amount of students during years 2000-2002. Numbers of registered students include all students who have registered - no matter whether they start to study at all. In each year there have been 10 to 50 students who actually did not do anything at all. Figures in parentheses give the amounts of female students. It is significantly lower than that for our ordinary students at the university. At the university the distribution between female and male students is almost even but in virtual CS studies the main part of, both started and graduated, students are male. The survey of Xenos et al. (2002) illustrates the very same results of female students' reluctance to start university level distance courses, and the dropouts in general.

Programming has proved to be the most difficult part in our program. In brief we can characterize that students who pass Programming I and Programming II, will very probably pass the rest of the courses as well. Cornell and Martin (1997) found that a students who has passed at least some distance courses, would probably also pass others in the future. Our findings agree with them (Meisalo et al., 2002b).

Furthermore we have been satisfied with our visualization tools: both interactive and non-interactive applets, Flash-animations and Jeliot 2000 program. Especially midperformers benefit from visualizations; an observation analyzed in detail by Ben-Bassat Levy et al. (2003). Masters et al. (2002) created several Java applets for the electrical engineering course and found out that simulations and on-line materials made it easier for students to take a more active role in learning. Animations have helped especially the understanding of difficult concepts. Our experiences support the findings of Master et al. (2002): animations of arrays, loops or binary search trees have helped students to understand these crucial structures of programming.

Table 3

Number of students in our on-line program

\begin{tabular}{cccc}
\hline Year & Number of high schools & Registered & Graduated \\
\hline 2000 & 12 & $89(14)$ & 20 \\
2001 & 21 & $184(24)$ & 37 \\
2002 & 19 & $156(22)$ & Ongoing \\
\hline
\end{tabular}




\section{Future Vision}

The Candle scheme is an outcome from a process where we designed an on-line course according to the actual needs of the potential users. The pros and cons of the scheme are rooted in this starting point. In particular, they can be seen in the future applicability of the Candle scheme.

The main advantage of the scheme is the relatively fast results it guarantees. This is based on, first, being sensitive to the students' authentic learning needs, and secondly, implementing the course in a light way. In our case, we had the first course implemented just after three months from the beginning of the project. This means, however, that the design and implementation process is followed by another process, called formative evaluation. Formative evaluation, utilizing both quantitative and qualitative methods for analyzing users' experiences and learning outcomes, identifies the weaknesses of the on-line program. The feedback must be taken into account by immediate modifications of the course.

The scheme emphasizes an extensive use of digital tools, like visualization environments. This is in contradiction to the commonly accepted emphasis on constructing mainly static - learning materials. We did not even try to replace a textbook but strived after using ICT in a functional way. Thus, we created smart learning gadgets for identified topics where students face learning difficulties. These tools can easily be transferred to other contexts as well.

Motivation, rather than the needs required by a certain paradigm of the subject area, has been the practical approach for organizing our learning materials. We think that online students need to be able to use their knowledge as fast as possible. In the area of programming, this means that exercises for producing animations have been more important than building a solid conceptual background.

In the future, we hope that we can light our Candle not only around our university but in other cultural contexts and for other subject areas as well. In fact, the candling process is about learning rather than designing. There are no more teachers at one end of the cable, students at the other one. There are just learners with slightly different roles. The learning environment is not primarily a clean and polished one, but of an inspiring and provocative character. A zone where one fights for understanding and mutual comprehension.

\section{Conclusions}

We developed our on-line Computer Science program as a part of the Virtual University of Finland funded by the Finnish Ministry of Education during 2001-2003. At the same time high school teachers of the surrounding rural area of the university were keen on to improve their CS teaching and asked whether the university could offer first year's university level CS studies to the high schools. Our department decided to combine these both interests and developed within this project virtual a CS program to high school students. 
The design model used in our on-line course creation process, the Candle scheme, proved to be a functional one. With Candle we have succeeded to focus our efforts on the highest priority items in the creation and evaluation process. Candle combines the essential elements in the on-line learning process from the view both of students and the university. Candle takes care of the students' need in learning process offering multiple ways of learning. In on-line courses equality of students and availability of services are the most essential elements, and Candle provides these both elements. Watanabe et al. (1999) noticed that the most difficult part in the creating process of distance learning programs seems to be to estimate the need for support that students will need during the study process. The Candle scheme focuses on that in multiple ways, on-line support complemented with face-to-face support given by tutor teachers at the local level.

Our scheme gives main guidelines for teachers who are going to create on-line courses, and we believe that Candle is likely expandable to other subjects or other countries as well. Our future interest is apply the Candle scheme to the developing countries for creating on-line CS programs in the third world.

\section{References}

Ben-Bassat Levy, R., M. Ben-Ari and P.A. Uronen (2003). The Jeliot 2000 program animation system. Computers and Education, 40 (1), 1-15.

Cordani, J.R., and R.J. Tucker (1998). Tools for higher education distance teaching. In Proceedings of the 26th SICUCCS Conference on User Services. Bloomington, USA, pp. 71-76.

Cornell, R., and B.L. Martin (1997). The role of motivation in web-based instruction. In B.H. Khan (Ed.), Web-Based Instruction. Educational Technology Publications. New Jersey, USA, pp. 93-106.

Dhanarajan, G. (2001). Distance education: promise, performance and potential. Open Learning, 16 (1), 61-68.

Ellis, A., D. Hagan, J. Sheard, J. Lowder, W. Doube, A. Carbone, J. Robinson and S. Tucker (1999). A collaborative strategy for developing shared Java teaching resources to support first year programming. In Proceedings of the 4th Annual SIGCSE/SIGCUE on Innovation and Technology in Computer Science Education. Krakov, Poland, pp. 84-87.

Farrell, G.M. (Ed.) (1999). A development of virtual education: a global perspective. In The Commonwealth of Learning. http://www.col.org/virtualed/index.htm

Farrell, G.M. (Ed.) (2001). The Chancing Faces of Virtual Education. The Commonwealth of Learning. http://www.col.org/virtualed/index2.htm

Haataja, A., J. Suhonen, E. Sutinen and S. Torvinen (2001). High school students learning computer science over the web. Interactive Multimedia Electronic Journal of Computer-Enhanced Learning (IMEJ), 3 (2). http://imej.wfu.edu/articles/2001/2/04/index.asp

Hope, A. (2001). Quality assurance. In G.M. Farrell (Ed.), The Chancing Faces of Virtual Education. The Commonwealth of Learning. http://www.col.org/virtualed/virtual2pdfs/V2_chapter7.pdf

Masters, J., T.M. Madhyastha and A. Shakouri (2002). Educational applets for active learning in properties of materials. The 2002 Frontiers in Education (FIE2002), Boston, USA.

http://fie.engrng.pitt.edu/fie2002/papers/1070.pdf

Meisalo, V., J. Suhonen, E. Sutinen and S. Torvinen (2002a). Formative evaluation scheme for a web-based course design. In Proceedings of 7th Annual Conference on Innovation and Technology in Computer Science Education (ITiCSE 2002). ACM Press, Aarhus, Denmark, pp. 130-134.

Meisalo, V., E. Sutinen and S. Torvinen (2002b). How to improve a virtual programming course? The 2002 Frontiers in Education (FIE2002), Boston, USA.

http://fie.engrng.pitt.edu/fie2002/papers/1180.pdf 
Suhonen, J., and E. Sutinen (2003). Portfolio-based analysis in developing tool for a web-based programming project course. Accepted to the IASTED International Conference on Computers and Advanced Technology in Education (CATE 2003), Rhodes, Greece.

Sumner, T., and J. Taylor (1998). New media, new practices: experiences in open learning course design. In Conference Proceedings on Human Factors in Computing Systems, Los Angeles, CA, USA, pp. 432-439.

Watanabe, S., T. Nakabayashi, H. Satoh, J. Tianfeng and T. Oda (1999). Web-based educational system: monitoring and assisting learners. In G. Cumming et al. (Eds.), Advanced Research in Computers and Communications in Education. IOS Press, pp. 693-700.

Xenos, M., C. Pierrakeas and P. Panagiotis (2002). A survey on student dropout rates and dropout cousescauses concerning the students in the course of informatics of the Hellenic Open University. Computers and Education, 39, 361-377.

E. Sutinen is a professor of computer science at the University of Joensuu. After receiving his $\mathrm{PhD}$ from the University of Helsinki in 1998, he has been working also at Purdue University, USA, and University of Linköping, Sweden. Currently, his main research focus is educational technology from the computer science point of view: how to design functional ICT tools to overcome learning barriers. He is a director for the Thinking Tools for the Net Project, funded by the National Technology Agency, Finland. He is also involved in applications such as Jeliot for programming visualizations, support collaborative learning by writing, and on-line computer science program for teaching.

S. Torvinen, MSc (2001) is a PhD student in CS. Her special interest is in educational technology and difficulties in virtual programming courses. She works as manager of the on-line CS project at the Department of Computer Science in the University of Joensuu. Her educational background is in educational technology in the field of computer science. Her research deals with the on-line CS program focusing to find the indicators of the learning process for the intervention in the virtual programming courses.

\section{"Žvakès" schema kuriant nuotolinio mokymo kompiuterijos programa: patirtis ir vizija}

\section{Erkki SUTINEN, Sirpa TORVINEN}

$2000 \mathrm{~m}$. Joensuu universiteto suprojektuota nuotolinio mokymo programa buvo tris metus trukusio projekto, skirto ikurti Suomijos Virtualų universitetą, dalies tąsa. Vienas iš specialių projekto tikslų - naujų kompiuterijos mokymo metodu parengimas ir plètotè. Dabar šiuo metodu mokomi mokiniai iš dvidešimties kaimo viduriniu mokyklu.

Straipsnyje apibūdinamas virtualios mokymo programos kūrimo procesas. Programa remiasi vadinamaja "žvakès" schema (Candle scheme). "Žvakẻs" schema atitinka svarbiausius principus, taikomus nuotolinèms studijoms bei padeda ivairiose vietose gyvenantiems studentams patenkinti jụ individualius poreikius pakankamai nesudètingu būdu: naudojantis elektroninėmis priemonemis. Pasitelkus "žvakès" schemą susikoncentruota ties esminių virtualaus mokymo dalių kūrimu.

Straipsnyje aprašytos autoriu sukurtos nedidelès mokymo priemonès, skirtos ivairioms temoms. Jas nesunku pritaikyti ir kitiems dalykams. Projektuojant mokymo medžiaga vyravo praktinis požiūris veikiau i motyvaciją nei i poreikius, reikalingus tam tikrai mokomojo dalyko paradigmai. Programavimo srityje tai reiškia, kad pratimų animacija labiau svarbi nei tvirto konceptualaus pagrindo suformavimas. Autoriai tikisi ateityje uždegti savo "žvakę" ne tik aplink Joensuu universitetą, bet ir kituose kultūriniuose kontekstuose bei kitose mokslo srityse. Iš esmès, šis procesas labiau susijęs su mokymusi, nei su projektavimu. Autorių sukaupta patirtis apie "žvakès" schemos taikymą sudarant kompiuterijos programą, skirtą nuotolinėms studijoms, rodo, jog ši schema yra funkcionali bei jos panaudojamumas gali būti išplèstas mokant ir kitų mokslo sričių. 